\title{
Report
}

\section{Public health issues and non-communicable diseases in Saskatchewan, Canada}

\author{
Muhammad A. Siddiqui a, Muhammad Owais Aziz b \\ a MBBS., MSc., PhD., Research and Performance Support, Saskatchewan Health Authority, Regina, Canada \\ ${ }^{b}$ MBBS., MSc., Clarkson University, New York, USA; St. Lawrence College, Cornwall, Ontario, Canada
}

Submitted date: 11.09.2018, Accepted date: 05.07.2019

\begin{abstract}
Objective: Main purpose of this paper was to report the occurrence of chronic non-communicable diseases such as diabetes, obesity, smoking, alcohol consumption and roadside injuries and its impact on the Saskatchewan healthcare system. Methods: We searched the Public Health Agency of Canada, Canadian Institute for Health Information website, electronic databases including Medline, Scopus, PubMed, and CINAHL to review published literature in this area. Electronic searches were limited to Health care, Diabetes, Obesity, Alcohol and Roadside injuries in Saskatchewan. Results: Obesity is associated with diabetes and hyperlipidemia. Insufficient fruit and vegetable intake may be associated with obesity but still there is a dire need of more research to understand of obesity. Smoking leads to chronic respiratory diseases, coronary artery disease and cancer, making it the leading cause of death. Impaired driving related injuries are the leading consequences of alcohol which is burdening the nation with millions of dollars annually. There is a need for an effective mass media campaign to develop awareness. Overall hospitalization due to traffic-accidents is on the decline nationally due to effective safety measures and enhancement of quality care. However, traffic accidents are still the leading cause of admission due to unintentional injuries. Conclusions: The key issues that needs to be addressed as a priority are those related to diabetes, obesity, alcohol and respiratory diseases that result in serious threat to the public health of Saskatchewan residents. Finally, promoting healthy living and positive behaviour can prevent incidence of these chronic conditions.
\end{abstract}

Key words: Health care, diabetes, obesity, alcohol, road side injuries

Corresponding Author: Muhammad A. Siddiqui, Research and Performance Support, Saskatchewan Health Authority, Regina, Canada Phone:306-519-4485 E-mail: drasadi@hotmail.com

Copyright holder Turkish Journal of Public Health

This work is licensed under a Creative Commons Attribution-NonCommercial 4.0 International License. (c) EY-NC This is an open Access article which can be used if cited properly. 


\section{Kanada Saskatchewan'da halk sağlığı sorunları ve bulaşıcı olmayan hastalıklar}

$\ddot{0} \mathbf{z}$

Amaç: Bu yazının temel amacı diyabet, obezite, sigara içme, alkol tüketimi ve yol kenarı yaralanmaları gibi kronik bulaşıcı olmayan hastalıkların ortaya çıkışı ve Saskatchewan sağlık sistemi üzerindeki etkisi hakkında bilgi vermektir. Yöntem: Bu konudaki yayınları gözden geçirmek için Kanada Halk Sağlığı Kurumu, Kanada Sağlık Bilgi Enstitüsü web sitesi, Medline, Scopus, PubMed ve CINAHL gibi elektronik veritabanlarını araştırdık. Elektronik aramalar "Saskatchewan'daki sağlık bakımı, diyabet, obezite, alkol ve yol kenarındaki yaralanmalar" olarak belirlendi. Bulgular: Obezite diyabet ve hiperlipidemi ile ilişkilidir. Yetersiz meyve ve sebze alımı obezite ile ilişkili olabilir, ancak obeziteyi anlamak için daha fazla araştırmaya ihtiyaç vardır. Sigara içmek kronik solunum yolu hastalıklarına, koroner arter hastalığına ve kansere yol açar ve bu nedenle ölümün önde gelen nedenidir. Hatalı sürüş kaynaklı yaralanmalar, ülkeye yılda milyonlarca dolar yük getiren alkolün önde gelen sonuçlarıdır. Farkındalık geliştirmek için etkili bir kitle iletişim kampanyasına ihtiyaç vardır. Trafik kazaları nedeniyle hastaneye yatış, etkili güvenlik önlemleri ve kaliteli bakımın artırılması ile ulusal düzeyde azalmaktadır. Ancak, trafik kazaları, kasıtsız yaralanmalar kaynaklı başvuruların halen önde gelen nedenidir. Sonuç: Öncelikli ele alınması gereken temel konular, Saskatchewan'da yaşayanların halk sağlığını tehdit eden diyabet, obezite, alkol ve solunum hastalıkları ile ilgilidir. Son olarak, sağlıklı yaşamı ve olumlu davranışı teşvik etmek bu kronik sağlık sorunlarının insidansını önleyebilir.

Anahtar kelimeler: Sağlık hizmeti, diyabet, obezite, alkol, yol kenarı yaralanmaları

\section{Introduction}

With the rapidly increasing illnesses, diseases and various disabilities, it is becoming difficult for not only governments but also healthcare providers and the general public to determine which form of illnesses should be addressed first. If a family or community is affected by a disease, for them that disease is automatically something to be prioritised. However, governmental officials and public health practitioners have to take care of everyone's health no matter what level of illness they might be facing. In Canada, most casualties occur due to diseases such as cancer, respiratory issues and illnesses related to the human circulatory system. There is also a high rate of illnesses caused by diabetes and obesity. ${ }^{1}$ According to the Canada Health Act (CHA) in 1984, the basic goals of healthcare management aim to protect, promote and rebuild the physical and mental welfare of Canadians. This Act also aided in the creation of an easy and low cost access to healthcare facilities without having any financial or other constraints. ${ }^{2}$ Different lifestyles play a vital role in increasing the likelihood of developing various diseases like heart disease, stroke and cancer in varying populations. However, several studies argue that differences in health issues among people cannot be solely blamed on lifestyle factors. As Marmot proposed, issues related to lifestyles were present within larger factors that result in illness and death. ${ }^{3}$ Lifestyle changes may well impact on the pattern of social networks. It is apparent that every sphere representing health determinants-except the inherited 
characteristics- is malleable to a certain extent.

The Public Health Agency works on the control and prevention of chronic diseases, injuries and infectious diseases. It prepares and responds to public's health related emergencies. It also broadcasts the medical advancements and expertise of Canada to the rest of the world. It utilizes the international researches and developments in Canada's public health programs. Moreover, it empowers the intergovernmental partnership linked to public health and aids the national methods associated with public health planning and policy. ${ }^{4}$ Canadians are becoming more aware of the benefits of public health involvement in various health sections like the evidence-based methods to avoid sickness and promote healthy lifestyles, which resulted in better health statuses of the citizens and minimised risk factors. ${ }^{5}$ However, the relationship with others and between governments can be further improved to gain a better knowledge of how to improve efforts in promoting health and deal with the health requirements of the Canadian population.

In 2017, the population of the Saskatchewan province was estimated to be around 1.16 million, as stated by Statistics Canada. ${ }^{6}$ Canada has divided the responsibilities of public medical health within the municipal, provincial or territorial and federal levels. ${ }^{7}$ The Government of Saskatchewan has ensured a detailed coverage of the universal health to all its residents through the Saskatchewan Health Authority. Majority of Canadian natives reside in the Saskatchewan province. ${ }^{8}$ Certain lifestyles have a negative effect on the health of these people, making them more prone to developing chronic diseases. ${ }^{9}$ Due to inflation, the maintenance of long term publicly funded health plan and services has become difficult. Chronic illnesses prevailing in the society has caused major losses in the productivity, including premature death, disability, decrease in the quality and effectiveness of work places and work absences. ${ }^{10}$ The purpose of this report was to provide an outline about the occurrence of various chronic illnesses such as Diabetes, Obesity, Smoking, Alcohol related hospitalization and injuries caused by accidents in the province of Saskatchewan.

\section{Material and method}

We searched electronic databases including Medline, Scopus, PubMed, CINAHL, and Cochrane to review published literature in this area to ensure a comprehensive assessment of relevant studies. Electronic searches were limited to Non-Communicable Diseases in Saskatchewan, Canada. Boolean operators were used for searching of relevant articles. Keywords included: Health care, Diabetes, Obesity, Alcohol, Roadside injuries and Saskatchewan.

We adopted tables and graphs utilizing publically available online Canadian Institute for Health Information. The Canadian Institute for Health Information is an independent, notfor-profit organization that provides essential information on Canada's health systems and the health of Canadians. Saskatchewan is a province located in western Canada. Saskatchewan is bordered on the west by Alberta, on the north by the Northwest Territories, on the east by Manitoba, to the northeast by Nunavut, and on the south by the U.S. states of Montana and North Dakota. In Saskatchewan, roughly half live in the province's largest city Saskatoon, or the provincial capital Regina. Other notable cities include Prince Albert, Moose Jaw, Yorkton, Swift Current, North Battleford, Melfort, and the border city Lloydminster (partially within Alberta). In winter, temperatures below -45 ${ }^{\circ} \mathrm{C}\left(-49^{\circ} \mathrm{F}\right)$ are possible even in the south during extreme cold snaps. The province's economy is based on agriculture, mining, and energy. 


\section{Results}

Diabetes

Diabetes is becoming increasingly common around the globe and according to a survey conducted in 2015, 415 million adults around the world were suffering from diabetes and this could further increase by 55 percent, which would be 642 million by 2040.11 In Canada alone, the obese or overweight people aged 18 or above were declared more prone to diabetes than the people with normal weight. In 2016, the occurrence of diabetes among obese Canadians was 13.2 percent; as compared to 6.6 percent in overweight people and 3.6 percent in the people with the normal weight. ${ }^{12}$

In 2016, the Canadian Diabetes Association presented an estimated occurrence of diabetes and pre-diabetes in Saskatchewan, which came out to be 28.5 percent, which makes $314,000.13$ Figure 1 gives an outline of the rate of diabetes occurrence per 100 for the population that is aged 18 or above between the years 2003 and 2013 in the province of Saskatchewan. The prevalence rate (per 100) of Saskatchewan population has increased from 5.5 to 7.6 during 2003 and 2013 as compared to the rise from 5.5 to 7.1 overall in Canada. From the years 2003 to 2013, the diabetes has been increasing rapidly among men residing in Saskatchewan from 5.4 to 9.2.

In the population aged 12 and above, $7 \%$ of Canadians were diagnosed with diabetes in 2016, which makes approximately 2.1 million people in total. ${ }^{12}$ The number of people having diabetes remained stable within the years 2015 and 2016 in Canada, of which $7.6 \%$ of men had more occurrences of diabetes than women (6.4\%). Diabetes showed an upward trend as the years pass for both males and females till they turn 64. People aged 75 or above did not have a high occurrence of diabetes.

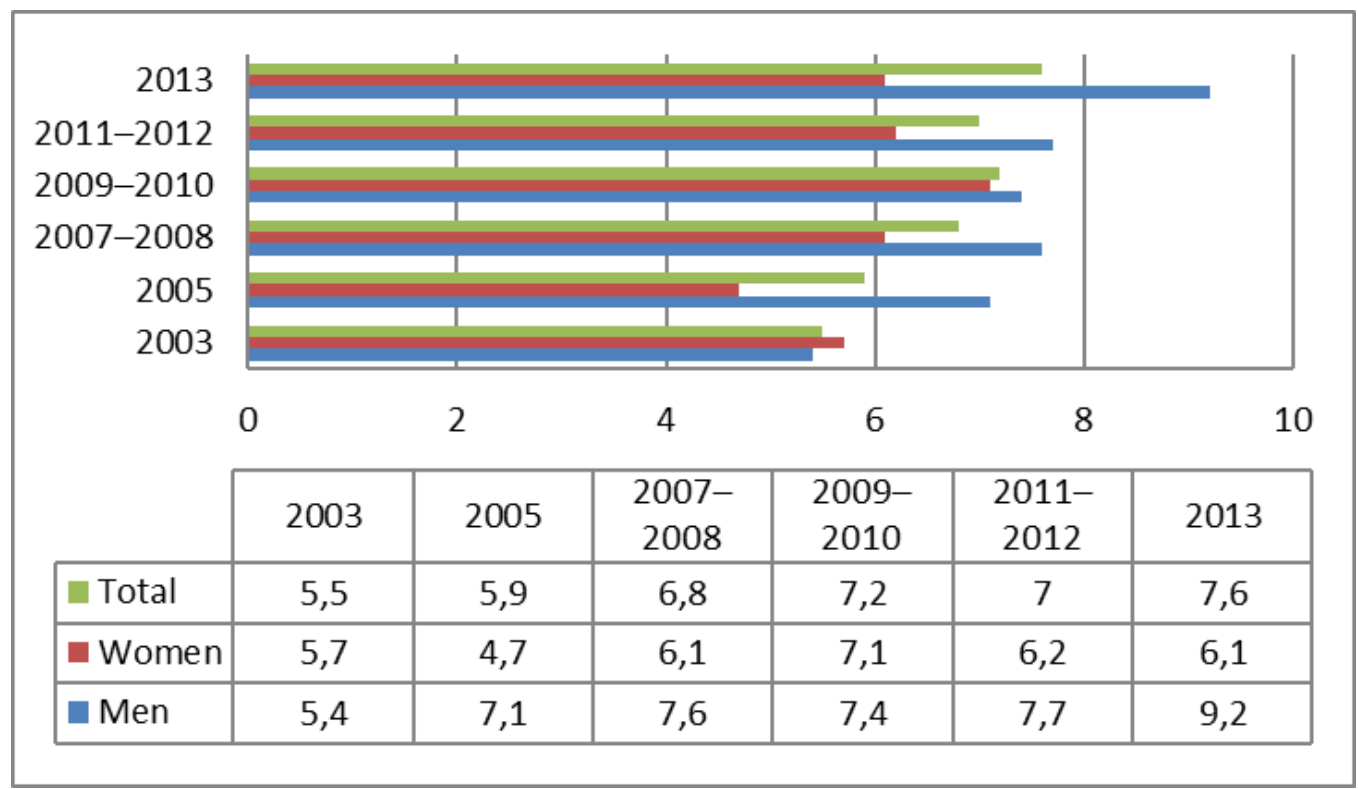

Figure 1. Age-standardized prevalence rate (per 100) of population age $\geq 18$ diagnosed with diabetes in Saskatchewan

Source: Adopted from Canadian Institute for Health Information data 
Due to the long term management related to the diabetic complications, its health care system costs have also spiked. ${ }^{14}$ If patients are well-informed about their illness then the health care costs can be reduced by cutting down the expenses on diabetic complication management. ${ }^{15}$ The basic purpose of the diabetic health education is to provide a low cost and preventative self-care management which is formed according to the diabetic educational training support that would aid in making the service delivery more efficient. With a joint reflective medical practice, the multidisciplinary team members would work passionately and effectively to create a balance as an active creator, find solutions for the hurdles in effective practice that contains a detailed reasonable diabetic care. Diabetic patients who live long distances from the healthcare centre and are unable to come due to transport issues or time restrains can avail detailed education through the distant counselling services.

Obesity

Globally, the body mass index (BMI) is directly linked to the increase in all-cause mortality of $\sim 30-40 \%$ per $5 \mathrm{~kg} / \mathrm{m}^{2}$ increase ${ }^{16}$. Obesity boosts the chances of type 2 diabetes to occur among overweight people ${ }^{8}$. As the body mass index (BMI) increases, the glucose and lipids get initially stored in the expanding (subcutaneous) adipose tissues ${ }^{9}$. There is higher obesity rate in the adults of Saskatchewan, which is about $25.1 \%$ as compared to the rest of the Canadians at $18.6 \%$. This is because the majority of the Saskatchewan residents do not have enough quantity of fruits and vegetables in their diets. According to Statistic Canada, ${ }^{17}$ only $36 \%$ of Saskatchewan residents reported eating fruits and vegetables at least five times a day which was lower than the Canadian average; the rate was much lower in men (29\%) than in women (43\%). The lower consumption of fruits and vegetables was consistently reported between 2003 and 2014.
According to the information collected from the Canadian Institute of Health Information (CIHI), regarding the national health status of the public, there has been a consistent increase in number of people with obesity $^{18}$. The approximate value of the rate of obesity is mostly collected through selfreported heights and weights, although sometimes the measured data has also been collected. According to Figure 2, there is a direct increase in the occurrence of obesity in Canadian adults aged 18 or older as shown by the self-reported data. The self-reported data is not the most accurate way to determine the extent of obesity as it underestimates the true level in Canada. There has been a significant increase in the rate of obesity in Saskatchewan province from 2003 to 2013. The male population was found to be more obese in both the provincial and Canadian population.

The issues of obesity and overweightness has caused several leaders from various backgrounds to deal with the most important public health issue of the country; the negative effects of excess weight and obesity on health. Excess weight can result in an early death or disability and can have adverse effects on the expenditure of health care, and productivity, and can result in social stigmatization. It is an extremely difficult task to calculate the intake of diet and physical activity of an individual or the whole population. This critical situation cannot be completely understood without thorough research.

\section{Smoking}

Smoking is one of the major factors that have caused injurious effects to the public's health in the form of several diseases or in some cases even death. Tobacco used in cigarettes is one of the most dangerous elements for the public health around the world, as it has killed more than 7 million people per year, of which 6 million deaths were reported to be of tobacco consumers while the rest were due to the nonsmokers being exposed to passive smoking. ${ }^{19}$ Passive smoking involves the smoke that is 
present in restaurants, offices or other spaces as a result of people burning tobacco products like cigarettes, bidis and water-pipes. Everyone should have the right to breathe in tobacco-free air. The smoke-free laws provide some protection to the non-smokers from breathing in bad air and they also do not affect the business in a negative way, while encouraging more people to quit smoking. In the year 2015, it was estimated that almost 4 million or just over 1 in 10 Canadians were smokers. ${ }^{20}$ Earlier in 2013, the rate of smoking in Saskatchewan was $24.6 \%$, which was more than the national average of $20.6 \%$. The prevalence of smoking is shown in Table 1 which indicates the overall prevalence, as well as the gender-specific prevalence in Saskatchewan from 2003-2013.
Despite an up-down trend in the prevalence of smoking, there still has been a consistent net increase during the years 2003 to 2008 , along with a stable decrease in the last few years. Males have been smoking more than females, despite having yearly varied differences in the genders. There are numerous harmful toxins present in the cigarette which include various constituents of tobacco and the products of pyrolysis. These detrimental ingredients in tobacco smoke causes exposure to a complex chemical mixture which results in the sudden serious physiologic effects to the smoker. ${ }^{21}$

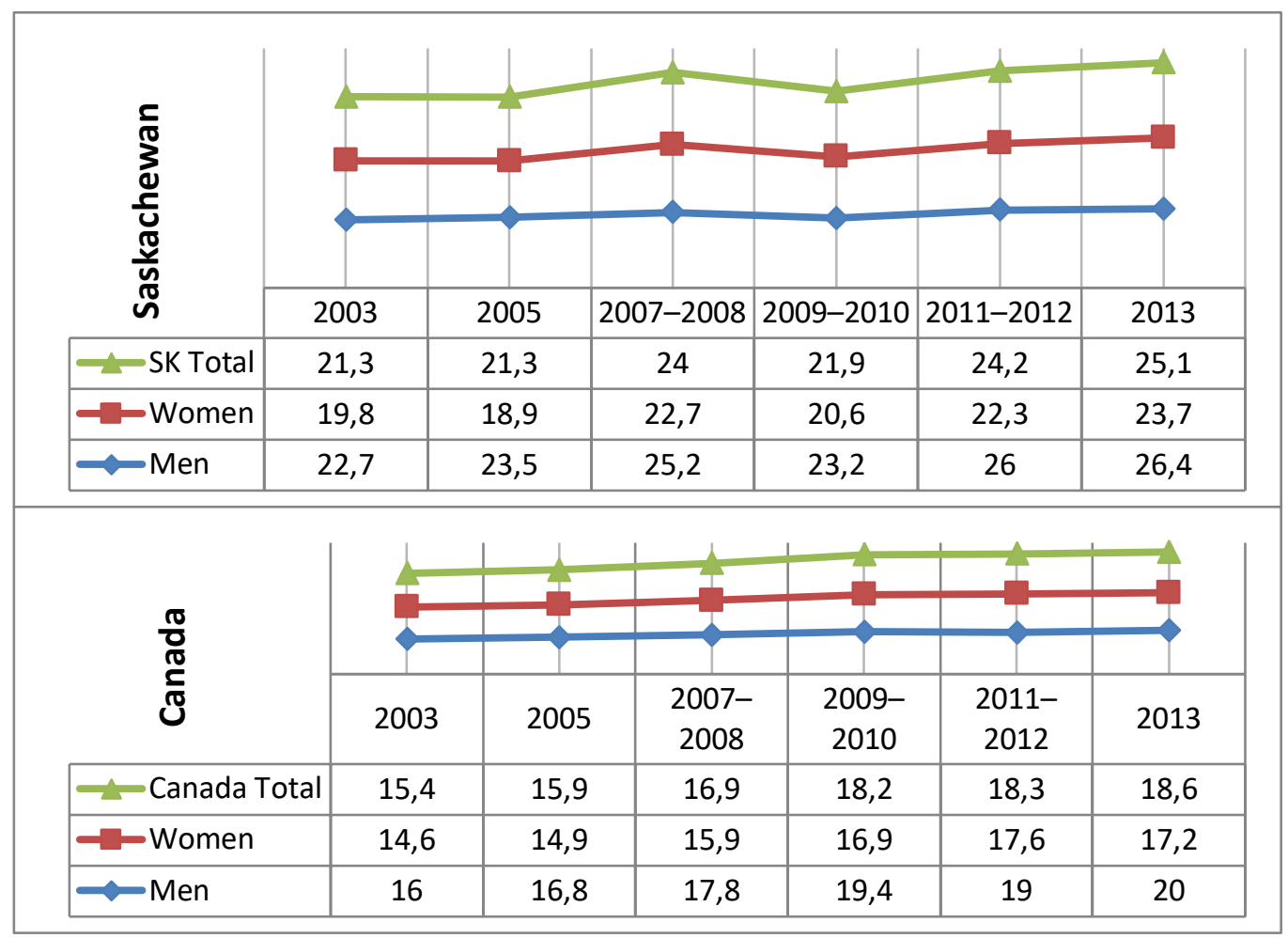

Figure 2. Age-standardized prevalence rate (per 100) of population age $\geq 18$ who were classified as obese based on self-reported height and weight

Source: Adopted from Canadian Institute for Health Information data 
Table 1. Age-standardized prevalence rate (percent? per 100) of population age $\geq 18$ who reported current cigarette smoking, either daily or occasionally

\begin{tabular}{lccc}
\hline Saskatchewan & Total & Men & Women \\
\hline $\mathbf{2 0 0 3}$ & $25.3(23.6-26.9)$ & $25.7(23.3-28.1)$ & $24.8(22.7-26.9)$ \\
$\mathbf{2 0 0 5}$ & $25.9(24.4-27.4)$ & $26.5(24.4-28.7)$ & $25.3(23.2-27.3)$ \\
$\mathbf{2 0 0 7 - 2 0 0 8}$ & $27.2(25.5-28.9)$ & $29.4(27.0-31.7)$ & $24.9(22.6-27.2)$ \\
$\mathbf{2 0 0 9 - 2 0 1 0}$ & $23.8(21.5-26.0)$ & $25.1(22.2-28.0)$ & $22.5(19.8-25.2)$ \\
$\mathbf{2 0 1 1 - 2 0 1 2}$ & $23.9(21.9-25.9)$ & $23.4(20.8-26.0)$ & $24.4(21.5-27.4)$ \\
$\mathbf{2 0 1 3}$ & $24.6(21.8-27.4)$ & $26.4(22.7-30.1)$ & $22.9(19.2-26.6)$ \\
\hline
\end{tabular}

Source: Adopted from Canadian Institute for Health Information data

The common respiratory problems in smokers include asthma, chronic obstructive pulmonary disease (COPD), lung cancer, and occupational lung diseases. The long term health issues and diseases caused by smoking around the world include coronary heart disease, cancer, and chronic obstructive pulmonary disease, or COPD 22. In 2009 alone, 7.5 million cases of COPD were reported in the United States. ${ }^{23}$ In 2010 more than 138,000 American citizens died from COPD, making it the third leading cause of death in the United States. ${ }^{24}$ COPD due to cigarette has approximately caused 80 percent deaths. ${ }^{25}$

Alcohol

Canadians have a long history of habitual drinking whose pattern has changed over the years, but around 3.1 million Canadians still regularly drink to the extent that they end up risking instant harm or injury, which also includes alcohol poisoning in certain circumstances. In the year 2013, around 22 million Canadians aged 15 years or above that made up 80 percent of the population drank alcohol, whereas the highest percentage of drinkers in the year before were aged between 30 to 34 years. ${ }^{26}$ Men are more into drinking than women; therefore, they also have a higher risk of being affected by it, as shown in the Figure 3. In the year 2014, around $18 \%$ of Canadians reported being heavy drinkers. In
Saskatchewan, the estimated percent of drinkers is $19.5 \%$ which is higher as compared to the overall rate of Canada. ${ }^{17}$ There was an increase in the hospitalizations due to alcoholattributable conditions for patients aged 15 or above in Saskatchewan and Canada during the years between 2007 and 2012, which is the age-standardized rate of per $100,000.18$ In 2015, the survey conducted by the Canadian Institute for Health Information in Saskatchewan, stated that the number of people hospitalized solely due to the intake of alcohol was 345 per 100,000 people.

Alcohol consumption and related issues resulted in high expenditures in the year 2002, when the overall cost for law enforcement, prevention and research and lost productivity of alcohol-related dangers in Canada went above 14 billion dollars. Out of this amount, 3.3 billion dollars were spent on health care 27 . Within a year, from 2014 to 2015 the hospitalization expenses of each individual admitted for the reasons of alcohol consumption was approximately 8,100 dollars, which is greater than the average hospital expenses of 5,800 dollars. ${ }^{28}$ The admissions on alcohol drinkers in hospitals cost more due to their longer stays, with an average of 11 days as compared to the 7 days normally spent in hospitals. ${ }^{29}$ 


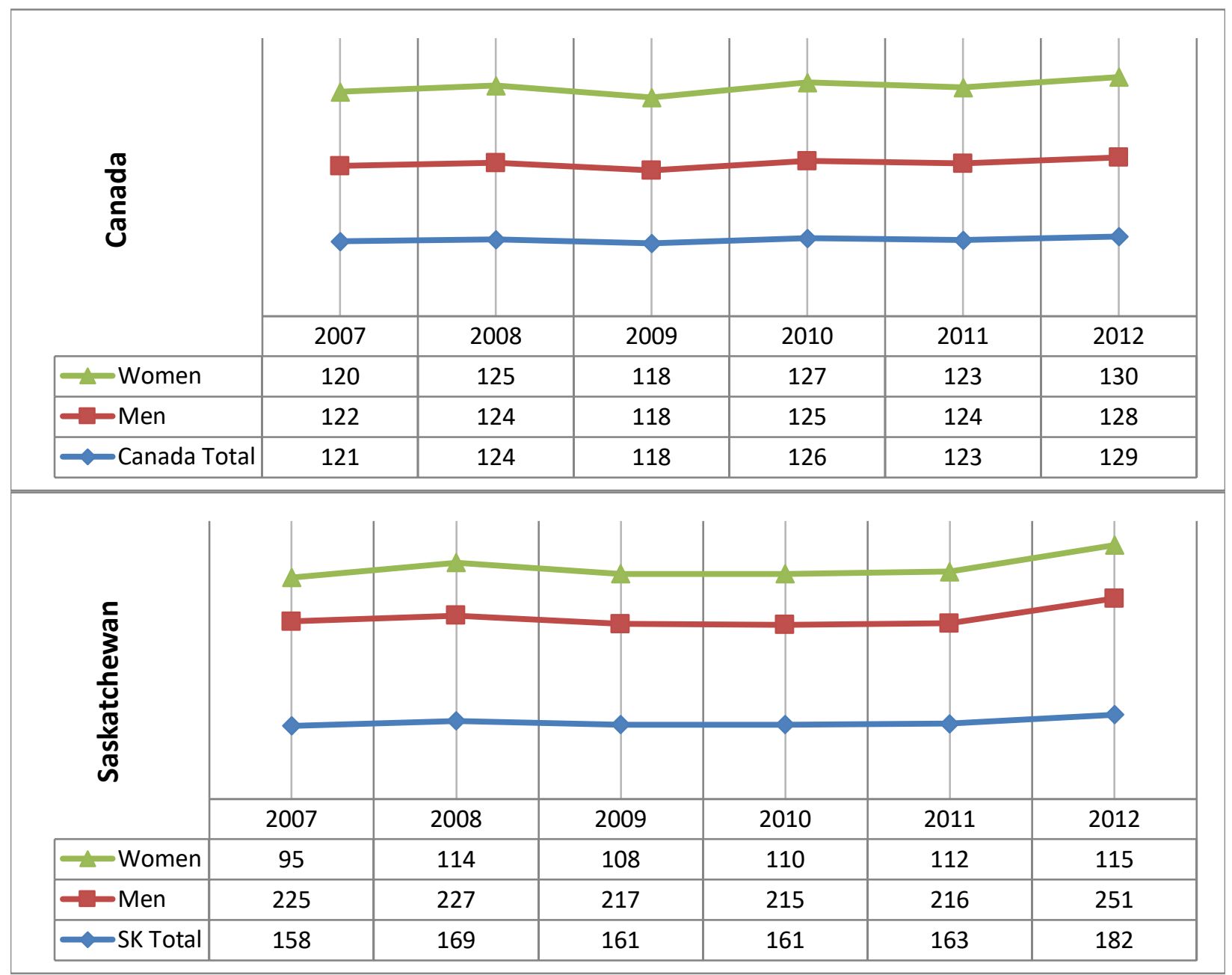

Figure 3. Age-standardized rate (per 100,000) of hospitalizations for alcohol-attributable conditions for patient's age $\geq 15$

Source: Adopted from Canadian Institute for Health Information data

Driving while being drunk or under influence of some drug can also cause financial constraints due to law enforcement and damage caused by the accidents. In 2010, the overall health and social expenses caused due to impaired driving which resulted in injuries, casualties and damage to vehicles was estimated to be more than 20.6 billion dollars. ${ }^{30}$ It is extremely essential to pay attention to the issue of increasing alcohol consumption of the residents of
Saskatchewan, so that they can be guided about the serious health risks that are associated with alcohol consumption. Running a campaign against the use of alcohol is a challenging task, as it is not easy to make effective messages regarding the harmful effects of alcohol. ${ }^{31}$ Therefore, only few mass media campaigns have been effective in raising awareness among people, as generally alcohol related campaigns are hardly ever successful. ${ }^{32}$ 


\section{Motor Vehicle Traffic Accidents}

Injuries caused by motor vehicle accidents largely contribute to the unintentional injuries and hospitalization, which is more common among the youth of Canada. ${ }^{33}$ Such accidents are also one of the major causes of premature deaths which were apparent in 2012, when 2100 Canadians died due to road accidents. ${ }^{34}$ According to the data collected from Discharge Abstract Database (DAD) and Hospital Morbidity Database (HMDB), the Canadian Institute for Health Information displayed an age-standardized rate of hospitalization caused by road injuries (per 100,000) during the years between 2007 and 2012. However, in recent years there has been a significant decrease in the motor vehicle accidents and impressive public health response in both the province of Saskatchewan and around Canada. If the rate of injuries caused by roadside accidents in Saskatchewan is compared with the rest of Canada, the province still remains at a higher number of men and women being hospitalised due to accidents. ${ }^{18}$ In addition, men get into accidents more than women and are hospitalized with minor or severe injuries in both Saskatchewan and Canadian, as depicted by the data in the Table 2. The decrease in hospitalizations could be due to several factors like the campaigns being run against drunk driving and stress on the use of seatbelts while driving and vehicle crashworthiness. ${ }^{35,36}$ In order to decrease drunk driving, there are various proposed remedies, such as a specific time period spent in analysis and testing or being linked with a possible increase in the chance of injury. ${ }^{37}$ The courses offered for improved driving and education courses are further linked with the crash involvement and violations. ${ }^{38}$ There have been some improved alterations in the designs of vehicles like the addition of antilock braking system (ABS) and electronic stability control (ESC) to avoid the possibility and decrease the impact of crashes. Moreover, there has been updated airbags that reduce the chances of head injuries of the driver during an accident. ${ }^{39}$ Numerous studies have appreciated the enhanced vehicle designs in reducing the rate of deaths. ${ }^{40-43}$ However, not much work has been done to identify the factor that played the biggest role in decreasing the rate of deaths caused by motor vehicle accident. The leading factor could be fewer crashes, better protection of the people in crash, other crash features or occupant features like their age that might also have changed along with the reduction in mortality. There is also minimal information present that is related to the non-fatal injuries, and nonhospital admissions that have also reduced. More efforts and work are required to minimize the crash incidence and the injuries that tend to affect an increasing number of people.

Table 2. Age-standardized rate (per 100,000) of hospitalizations due to injury resulting from motor vehicle traffic accidents

\begin{tabular}{|c|c|c|c|c|c|c|}
\hline & $\begin{array}{c}2007 \\
\text { n }(95 \% \mathrm{CI})\end{array}$ & $\begin{array}{c}2008 \\
\text { n }(95 \% \mathrm{CI})\end{array}$ & $\begin{array}{c}2009 \\
\text { n }(95 \% \mathrm{CI})\end{array}$ & $\begin{array}{c}2010 \\
\text { n }(95 \% \mathrm{CI})\end{array}$ & $\begin{array}{c}2011 \\
\text { n (95\% CI) }\end{array}$ & $\begin{array}{c}2012 \\
\text { n }(95 \% \mathrm{CI})\end{array}$ \\
\hline Men (SK*) & $\begin{array}{c}114 \\
(105-124)\end{array}$ & $\begin{array}{c}120 \\
(110-130)\end{array}$ & $\begin{array}{c}113 \\
(103-122)\end{array}$ & $\begin{array}{c}107 \\
(98-117)\end{array}$ & $\begin{array}{c}107 \\
(97-116)\end{array}$ & $\begin{array}{c}105 \\
(95-114)\end{array}$ \\
\hline Women (SK) & $69(61-76)$ & $68(60-75)$ & $70(62-77)$ & $65(58-72)$ & $64(56-71)$ & $67(59-74)$ \\
\hline SK Total & 91 (85-97) & $93(87-100)$ & 91 (85-97) & 85 (79-91) & 85 (79-91) & 85 (79-91) \\
\hline $\operatorname{Men}\left(\mathrm{Ca}^{* *}\right)$ & $72(71-73)$ & $67(66-69)$ & $63(62-64)$ & $62(60-63)$ & $61(59-62)$ & $59(58-60)$ \\
\hline Women (Ca) & $42(41-43)$ & $38(37-39)$ & 37 (36-38) & $36(35-37)$ & $35(34-36)$ & $34(33-35)$ \\
\hline Canada Total & $56(56-57)$ & $52(51-53)$ & $50(49-51)$ & $48(48-49)$ & $47(47-48)$ & $46(45-47)$ \\
\hline
\end{tabular}

*Saskatchewan ** Canada, Source: Adopted from Canadian Institute for Health Information data 


\section{Conclusion}

A public health approach requires an effort to deal with the inequalities in health and improving the health of people of Saskatchewan. The key issues that need to be addressed on a priority basis are those related to diabetes, obesity, alcohol and lung diseases that result in serious threat to the public health of Saskatchewan residents and all over Canada. There is a dire need for the appropriate public health actions to be taken against these prevalent issues. It is possible to establish a healthy lifestyle and avoid injuries and chronic illnesses through promotion of healthy living and positive change of behaviour and attitude among the citizens of Canada.

Ethics Approval and Consent to Participate:

Not applicable

Consent for Publication: Not applicable

Availability of data and material: Not applicable

Authors' contributions: MAS conceived the study. MAS performed literature review and MAS, MOA developed the manuscript. MAS provided extensive feedback and mentorship throughout the project. All authors read, provided feedback, and approved the final manuscript.

Conflict of interest: The authors declare that they have no competing interests Financial support: No funding was obtained. Acknowledgements: The authors show appreciation to the staff at Canadian Institute for Health Information for maintaining the database. Available publically at < https://www.cihi.ca/en/access-datareports/results?f\%5B0\%5D=field_primary_th eme $\% 3$ A2064\&page $=1>$

\section{References}

1. Public Health Agency of Canada . The Chief Public Health Officer's Report on the State of Public Health in Canada. Ottawa: . 2008.
2. Government of Canada. Canada Health Act. Retrieved from Minister of Justice website: . [Online]. 1984; < http://laws-lois.justice.gc.ca/PDF/C6.pdf > (Accessed Jan 2018).

3. Marmot MG. Social inequalities in mortality: The social environment. In Class and health: Research and longitudinal data. Edited by R.G. Wilkinson. Tavistock, London 1986.

4. Public Health Agency of Canada About the agency. [Online]. 2012; < www.phac-

aspc.gc.ca/about_apropos/indexeng.php> (Accessed April 20, 2017).

5. Verma J, Petersen S, Samis S, Akunov N, Graham J. Healthcare Priorities in Canada: A Backgrounder. Canadian Foundation for Healthcare Improvement. [Online]. 2014; < https://www.cfhi-fcass.ca/sf-

docs/default-

source/documents/harknesshealthcare-priorities-canadabackgrounder-e.pdf > (Accessed May 2018).

6. Statistics Canada. Table 051-0001 Estimates of population, by age group and sex for July 1, Canada, provinces and territories, annual (persons unless otherwise noted), CANSIM (database). [Online]. http://www5.statcan.gc.ca/cansim/a $47>$ (Accessed Oct, 2017).

7. Fierlbeck K. Public health and collaborative governance. Can Public Admin. 2010;53:1-19.

8. Diabetes: Canada at the Tipping Point - Charting a New Path. [Online]. < https://www.diabetes.ca/CDA/media /documents/publications-andnewsletters/advocacyreports/canada-at-the-tipping-pointenglish.pdf > (Accessed Jan, 2018).

9. Bloom DE, Cafiero ET, Jané-Llopis E, et al. The Global Economic Burden of Non-communicable Diseases. Geneva: World Economic Forum. 2011. 
10. Public Health Agency of Canada. Backgrounder United Nations NCD summit. Chronic diseases-most significant cause of death globally. Ottawa. [Online]. 2011; < http://www.phacaspc.gc.ca/media/nrrp/2011/2011_0919-bg-di-eng.php > (Last accessed June 2017).

11. International Diabetes Federation. IDF Diabetes Atlas. 7th edn. Brussels, Belgium: International Diabetes Federation, 2015. [Online]. < http://www.diabetesatlas.org > (Accessed Dec, 2017).

12. Health Fact Sheets Diabetes. [Online]. 2016; http://www.statcan.gc.ca/pub/82625-x/2017001/article/54859eng.htm > (Accessed Feb, 2018).

13. Diabetes in Saskatchewan - Diabetes Canada. [Online]. < https://www.diabetes.ca/getmedia/0 c6c68e0-21dc-4e9e-b2a8-

$9 \mathrm{e} 546 \mathrm{ef} 899 \mathrm{cc} /$ diabetes-charterbackgrounder-sk-2016-06.pdf.aspx > (Accessed Dec, 2017).

14. Clarke P, Gray A, Legood R, Briggs A, Holman R. The impact of diabetesrelated complications on healthcare costs: results from the United Kingdom Prospective Diabetes Study (UKPDS Study No. 65). Diabet. Med. 2003;20:442-50.

15. Herman WH, Eastman RC. The effects of treatment on the direct costs of diabetes. Diabetes Care. 1998;21:1924.

16. Fierlbeck K. Public health and collaborative governance. Can Public Admin. 2010;53:1-19.

17. Statistics Canada. Table 105-0501 Health indicator profile, annual estimates, by age group and sex, Canada, provinces, territories, health regions (2013 boundaries) and peer groups (occasional) [Data File]. [Online]. 2015; < http://www5.statcan.gc.ca/cansim/a 26?lang=eng\&retrLang=eng\&id=1050 501\&pattern $=\&$ csid $>$ (Accessed Jan, 2018).

18. Canadian Institute of Health Information (CIHI). Access Data and Reports. [Online]. < https://www.cihi.ca/en/access-datareports/results?f\%5B0\%5D=field_geo graphies\%3A1966 > (Accessed Nov, 2017).

19. World Health Organization. Tobacco. Fact sheet. [Online]. < http://www.who.int/mediacentre/fa ctsheets/fs339/en/ > (Accessed Feb, 2018).

20. Health Status of Canadians 2016: Report of the Chief Public Health Officer - What is influencing our health? - Smoking. [Online]. < https://www.canada.ca/en/publichealth/corporate/publications/chiefpublic-health-officer-reports-statepublic-health-canada/2016-healthstatus-canadians/page-14-whatinfluencing-health-smoking.html > (Accessed Jan, 2018).

21. Centers for Disease, Control Prevention, National Center for Chronic Disease, Prevention Health, Promotion Office on, Smoking Health, Publications and Reports of the Surgeon General. How Tobacco Smoke Causes Disease: The Biology and Behavioral Basis for SmokingAttributable Disease: A Report of the Surgeon General. Atlanta (GA): Centers for Disease Control and Prevention (US); 2010.

22. HHS (Department of Health and Human Services). The health consequences of smoking - 50 years of progress: A report of the Surgeon General. Atlanta, GA: U.S. Department of Health and Human Services, Centers for Disease Control and Prevention, National Center for Chronic Disease Prevention and Health Promotion, Office on Smoking and Health. 2014.

23. Rostron BL, Chang CM, Pechacek TF. Estimation of cigarette smokingattributable morbidity in the United 
States. JAMA internal medicine. 2014;174:1922-8.

24. Heron M. Deaths: leading causes for 2010. Natl. Vital Stat. Rep. 2013;62:196.

25. HHS (Department of Health and Human Services). The health consequences of smoking: A report of the Surgeon General. Atlanta, GA: U.S. Department of Health and Human Services, Centers for Disease Control and Prevention, National Center for Chronic Disease Prevention and Health Promotion, Office on Smoking and Health. 2004.

26. Health Canada. Canadian Tobacco, Alcohol and Drugs Survey, 2013. All computations on these microdata were prepared by the Public Health Agency of Canada and the responsibility for the use and interpretation of these data is entirely that of the author(s). 2015.

27. Rehm J, Baliunas D, Brochu S, et al. The Cost of Substance Abuse in Canada 2002. . Canadian Centre on Substance Abuse (CCSA) 2006.

28. Canadian Institute for Health Information. National Health Expenditure Database. [Online]. 2016; $<$ https://www.cihi.ca/en/nationalhealth-expenditure-databasemetadata > (Accessed Sep, 2017).

29. Canadian Institute for Health Information. Quick Stats: DAD/HMDB hospitalization rate, average length of stay, top 10 high-volume inpatient hospitalizations and surgeries, and hospital-based newborn rate, 20142015. https://www.cihi.ca/en/quick-stats > (Accessed April, 2017).

30. Pitel S, Solomon R. Estimating the number and cost of impairmentrelated traffic crashes in Canada: 1999 to 2010. Mothers Against Drunk Driving. 2013.

31. OECD. Tackling harmful alcohol use: Economics and public health policy. OECD Publishing. 2015.
32. Wakefield MA, Loken B, Hornick RC. Use of mass media campaigns to change health behavior. Lancet. 2010;376:1261-71.

33. Public Health Agency of Canada. Injury in Review 2012: Spotlight on Road and Transport Safety. Ottawa, ON: PHAC; . 2012.

34. Transport Canada. Canadian Motor Vehicle Traffic Collision Statistics 2011. Ottawa, ON: Transport Canada; 2013. [Online]. http://www.tc.gc.ca/media/documen ts/roadsafety/ > (Accessed Oct, 2017).

35. Motor-vehicle safety: a 20th century public health achievement. MMWR Morb. Mortal. Wkly. Rep. 1999;48:36974.

36. Waller PF. Challenges in motor vehicle safety. Annu. Rev. Public Health. 2002;23:93-113.

37. Dinh-Zarr T, Goss C, Heitman E, Roberts I, DiGuiseppi C. Interventions for preventing injuries in problem drinkers. Cochrane Database Syst. Rev. 2004:Cd001857.

38. Vernick JS, Li G, Ogaitis S, MacKenzie EJ, Baker SP, Gielen AC. Effects of high school driver education on motor vehicle crashes, violations, and licensure. Am. J. Prev. Med. 1999;16:40-6.

39. Dischinger PC, Ryb GE, Kufera JA, Ho SM. Declining Statewide Trends in Motor Vehicle Crashes and InjuryRelated Hospital Admissions. Ann. Adv. Automot. Med. 2013;57:247-56.

40. National Highway Traffic Safety Administration . Trends in Non-Fatal Traffic Injuries: 1996-2005. U.S. . Department of Transportation; May, 2008. DOT HS 810944.

41. Crandall CS, Olson LM, Sklar DP. Mortality reduction with air bag and seat belt use in head-on passenger car collisions. Am. J. Epidemiol. 2001;153:219-24.

42. Farmer CM, Lund AK. Trends over time in the risk of driver death: what if 
vehicle designs had not improved?

Traffic Inj Prev. 2006; 7:335-42.

43. Ryb GE, Dischinger PC, Ho S. Vehicle

model year and crash outcomes: a
CIREN study. Traffic Inj Prev. 2009 10:560-6. 